\title{
Long-term vigabatrin treatment modifies pentylenetetrazole-induced seizures in mice: focused on GABA brain concentration
}

\author{
Mariusz J. Świąder ${ }^{1} \cdot$ Katarzyna Świąder $^{2} \cdot$ |zabela Zakrocka $^{3} \cdot$ Maciej Krzyżanowski $^{4} \cdot$ Andrzej Wróbel $^{5}$. \\ Jarogniew J. Łuszczki ${ }^{4}$. Stanisław J. Czuczwar ${ }^{4}$
}

Received: 18 June 2019 / Revised: 24 September 2019 / Accepted: 11 October 2019 / Published online: 20 December 2019

(c) The Author(s) 2019, corrected publication 2020

\begin{abstract}
Background The goal of our study was to examine the long-term effect of vigabatrin (VGB), a $\gamma$-aminobutyric acid aminotransferase (GABA-AT) inhibitor on clonazepam (CLO), ethosuximide (ETX) and valproate (VPA) anticonvulsive activity against pentylenetetrazole (PTZ)-induced seizures in mice.

Methods VGB was administered for 3 and 7 days. Convulsions were evoked by PTZ at its CD97 (99 mg/kg). The influence of CLO, ETX and VPA alone or in combination with VGB on motor performance and long-term memory was analyzed. $\gamma$-aminobutyric acid (GABA) concentration in mice brain and plasma as well as glutamate decarboxylase (GAD) activity was measured.

Results After 3 days of treatment, VGB in doses up to $500 \mathrm{mg} / \mathrm{kg}$ increased PTZ-induced seizure threshold, whereas after 7 days VGB (at the dose of $125 \mathrm{mg} / \mathrm{kg}$ ) inhibited clonic seizures in experimental mice. 7 days of VGB administration did not change the protective effect of CLO, ETX and VPA against PTZ-induced seizures. 7 days of VGB treatment at a subthreshold dose of $75 \mathrm{mg} / \mathrm{kg}$ decreased TD50 of ETX and CLO in the chimney test, but did not affect TD50 value for VPA. 7 days of VGB administration in combination with AEDs did not affect long-term memory in mice. VGB after 3 days or 7 days of administration increased brain GABA concentration. GAD activity was decreased after 3 and 7 days of VGB administration. Conclusions The presented results confirm anticonvulsive activity of VGB through GABA metabolism alteration and suggest care when combining VGB with ETX or CLO in the therapy.
\end{abstract}

Keywords Vigabatrin $\cdot$ Pentylenetetrazole $\cdot$ Seizures $\cdot$ GABA decarboxylase $\cdot$ Antiepileptic drugs

$\begin{array}{ll}\text { Abbreviations } \\ \text { AEDs } & \text { Antiepileptic drugs } \\ \mathrm{CD}_{97} & \text { Convulsive dose } \\ \mathrm{CLO} & \text { Clonazepam } \\ \mathrm{ED}_{50} & \text { Median effective dose }\end{array}$

Mariusz J. Świąder

mariusz.swiader@umlub.pl

1 Department of Experimental and Clinical Pharmacology, Collegium Pathologicum, Medical University of Lublin, ul. Jaczewskiego 8b, 20-090 Lublin, Poland

2 Department of Applied Pharmacy, Medical University of Lublin, ul. Chodźki 1, 20-093 Lublin, Poland

3 Department of Nephrology, Medical University of Lublin, ul. Jaczewskiego 8, 20-090 Lublin, Poland

4 Department of Pathophysiology, Medical University of Lublin, ul. Jaczewskiego 8b, 20-090 Lublin, Poland

5 2nd Department of Gynecology, Medical University of Lublin, ul. Jaczewskiego 8, 20-090 Lublin, Poland

$\begin{array}{ll}\text { ETX } & \text { Ethosuximide } \\ \text { GABA } & \gamma \text {-Aminobutyric acid } \\ \text { GABA-AT } & \gamma \text {-Aminobutyric acid aminotransferase } \\ \text { GAD } & \text { Glutamate decarboxylase } \\ \text { ip } & \text { Intraperitoneally } \\ \text { mTOR } & \text { Mammalian target of rapamycin } \\ \text { PTZ } & \text { Pentylenetetrazole } \\ \text { sc } & \text { Subcutaneously } \\ \text { TCA } & \text { Trichloroacetic acid } \\ \text { TD } & \text { Median toxic dose } \\ \text { VGB } & \text { Vigabatrin } \\ \text { VPA } & \text { Valproate }\end{array}$

\section{Introduction}

Epilepsy is a worldwide neurological disorder affecting around 70 million patients [1]. In addition to lowering patients' life quality, epilepsy increases the risk of premature 
death and may shorten life expectancy by $2-10$ years [2]. Despite the introduction of many promising antiepileptic drugs (AEDs), it is estimated that around one-third of the patients suffer from drug-resistant seizure attacks [3]. In such patients, treatment with one AED might be ineffective; however, polytherapy with AEDs apart from clinical effectiveness [4] is linked with higher risk of side effects [5]. Vigabatrin (VGB, $\gamma$-vinyl $\gamma$-aminobutyric acid) remains one of the most effective AED, especially in drug-resistant partial seizures [6].

The main mechanism of VGB action is an irreversible inhibition of $\gamma$-aminobutyric acid (GABA) transaminase (GABA-AT) [7]. Long-term anticonvulsive effect of VGB is especially correlated with GABA elevation in the central nervous system, without affecting dopamine and norepinephrine levels [8]. However, one of the most important inhibitory amino acids, glycine, was shown to potentiate VGB effect in a rat model of genetic absence epilepsy [9]. In addition, a dose-dependent reduction in glutamate level in the rat hippocampus as well as lower aspartate and glutamate concentrations in the cortex, hippocampus and cerebellum was reported after 12 days of intraperitoneal VGB administration [10]. Similar observations were made by Engelborghs et al. [11] in audiogenic rats, suggesting that the anticonvulsive properties of VGB are not only dependent on GABA-AT inhibition.

Experimental data confirmed VGB anti-seizure efficacy in pilocarpine-induced seizures in rats [12], amygdala-kindled rats [13] and rats with absence seizures [14]. Moreover, VGB was effective in pentylenetetrazole (PTZ)-induced seizures [15] and kainic acid-induced seizures in rats [16]. Neuroprotective properties of VGB, especially in rat hippocampus, were also shown [16]. Interestingly, VGB was reported to decrease seizure susceptibility and seizureinduced mortality in hypobaric hypoxia in rats [17]. Inhibition of mammalian target of rapamycin (mTOR) pathway and glial proliferation in mice is an intriguing novel mechanism of VGB action, showing VGB usefulness in tuberous sclerosis treatment [18].

According to clinical data, VGB is useful as an add-on therapy in partial onset seizures [19] and infantile spasm treatment, especially in tuberous sclerosis [20]. Unfortunately, despite broad anticonvulsive activity and limited effect on mood and behavior, VGB may have a negative impact on myoclonic [21] and absence seizures [22] or patients with concomitant Parkinson's disease [23] and psychosis [24]. Retinopathy with the development of peripheral visual field defects is another reason of VGB treatment discontinuation [25].

In a previous study, the effect of acute VGB administration on anticonvulsive effect of other AEDs in PTZinduced seizures in mice was presented [26]. The goal of our study was to analyze the influence of 3 and 7 days of
VGB administration on clonazepam (CLO), ethosuximide (ETX) and valproate (VPA) efficacy in mice challenged with seizures evoked by PTZ. To assess VGB side effects, motor impairment and long-term memory tests were performed. The concentrations of CLO, ETX and VPA in the brain and plasma in mice after VGB administration were also analyzed. What is more, the concentrations of GABA and glutamate decarboxylase (GAD) activity, a key enzyme involved in GABA synthesis, in mice brain homogenates were examined.

\section{Materials and methods}

\section{Animals}

Tests were performed on male Swiss mice (weight 20-27 g, age 5 weeks). Animals were housed under standard laboratory conditions in colony cages with water and food (Murigran pellets, Bacutil, Motycz, Poland) available ad libitum. The examined mice were kept at $20{ }^{\circ} \mathrm{C}$ and on 12-h light-dark cycles. After 7 days of adaptation, the mice were divided into experimental groups containing 8-12 animals. Every experiment was performed between 9 a.m. and 1 p.m. Each mouse was tested only once. Experimental procedures were accepted by the Local Ethics Committee for Animal Experiments in Lublin and are in agreement with Directive 2010/63/EU on the protection of animals used for scientific purposes. Each mouse was tested only once.

\section{Chemical substances}

CLO (Polfa, Warszawa, Poland), ETX (Sigma-Aldrich, St. Louis, MO, USA), VPA magnesium salt (ICN Polfa Rzeszów, Poland) and VGB (Sabril, Laboratories, Casenne, France) were used in the presented study. PTZ was purchased from Sigma-Aldrich (St. Louis, MO, USA). PTZ, ETX and VPA were prepared as water solutions, whereas CLO and VGB were dissolved in a $1 \%$ solution of Tween 80 (SigmaAldrich, St. Louis, MO, USA). Every AED was injected intraperitoneally (ip) in $0.01 \mathrm{ml} / \mathrm{g}$ volume; however, PTZ was administered $s c$ in $0.05 \mathrm{ml} / \mathrm{g}$ volume, respectively. The animals received once daily injections of VGB for 7 days, and on the last day the mice were co-administered with one of the AEDs tested. CLO and VPA were injected $30 \mathrm{~min}$ and ETX 45 min before animal testing. AEDs were administered at their peak anticonvulsive activity time according to previous studies [27, 28]. VGB was injected $60 \mathrm{~min}$ before every test, as reported by Bernasconi et al. [29].

Substances used to analyze GABA brain concentrations (glutamic acid, sodium phosphate buffer, ninhydrin, sodium carbonate buffer, tartaric acid, copper sulfate pentahydrate, hydrochloric acid, trichloroacetic acid, distilled water) or 
to examine GAD activity (phosphate buffer, glutamic acid, pyridoxal phosphate, carbonate buffer, ninhydrin) were purchased from Sigma-Aldrich (St. Louis, MO, USA).

\section{Animal experiments}

\section{Seizure activity}

The mice received subcutaneously ( $s c$ PTZ at the dose of $99 \mathrm{mg} / \mathrm{kg}$, which is a convulsive dose $\left(\mathrm{CD}_{97}\right)$ for PTZ to induce clonic convulsions. The mice were then put into clear cages $(25 \times 15 \times 10 \mathrm{~cm})$, in which they were observed for $30 \mathrm{~min}$ if clonic seizures occurred. Clonic seizure activity was defined as a whole body clonus lasting longer than $3 \mathrm{~s}$ with the loss of righting reflex.

\section{Chimney test}

The influence of AEDs alone or given concomitantly with VGB on mice motor performance was analyzed in the chimney test as showed by Boissier et al. [30]. The animals climbed backward up a plastic tube $(3 \mathrm{~cm}$ inner diameter, $25 \mathrm{~cm}$ long). Motor impairment was defined by the mice having the inability to climb the tube backward within $60 \mathrm{~s}$. $24 \mathrm{~h}$ before drug administration, the mice were pretrained and the animals unable to perform the test were excluded from the experimental groups (each group comprised 8 animals). All examined substances were given $i p$. The obtained results were presented as $\mathrm{TD}_{50}$ values of AEDs.

\section{Passive avoidance acquisition and retention tests}

The step-through passive avoidance task was performed as presented by Venault et al. [31]. After pretreatment the animals were put in an illuminated box $(10 \times 13 \times 15 \mathrm{~cm})$ connected with a second larger dark container $(25 \times 20 \times 15 \mathrm{~cm})$ with an electric grid floor. Every entry into the dark box was punished by an electric foot shock ( $0.6 \mathrm{~mA}$ for $2 \mathrm{~s})$. The mice which did not enter the dark container in $60 \mathrm{~s}$ were rejected from the study. The next day ( $24 \mathrm{~h}$ later), the nontreated animals were again put into the illuminated box and the mice avoiding the dark container longer than $180 \mathrm{~s}$ were qualified as remembering the task. Retention was analyzed as a median (s) with 25 and 75 percentiles needed to enter the dark box.

\section{Quantification of free plasma and brain concentration of antiepileptic drugs levels}

AEDs concentrations in plasma and brain were quantified according to the method presented by Czuczwar et al. [32] and Świąder et al. [33]. The animals received one from the studied AED and saline (control group) or VGB (250 mg/ $\mathrm{kg}$ ) and analyzed AED. After mice decapitation at times scheduled for the convulsive test, blood samples ( $1 \mathrm{ml}$ volume) were collected into test tubes. Mice brains were rapidly removed from the skulls, weighed and homogenized with the use of Abbott buffer (1:2, w/v; Abbott Laboratories, North Chicago, IL, USA) in an Ultra-Turrax T8 homogenizer. Then blood samples and brain homogenates were centrifuged at 10,000 rpm (Abbott centrifuge, Irving, TX, USA) and transported to a micro-partition system (MPS-1, Amicon, Denvers, MA, USA). Afterward, the obtained plasma samples and brain supernatants $(100 \mu \mathrm{l})$ were analyzed by immunofluorescence, using an Abbott TDx analyzer (Abbott) and reagents as described by the manufacturer. To verify the calibration, control plasma and brain samples containing AEDs were used. Plasma and brain drug concentrations were calculated in $\mu \mathrm{g} / \mathrm{ml}$ or $\mu \mathrm{g} / \mathrm{g}$ of wet brain tissue as a mean $\pm \mathrm{SD}$ (at least 8 results were used).

\section{The analysis of GABA concentration in the mouse brain after 7 days of VGB administration}

GABA brain level was analyzed in the mouse brain homogenates as shown by Lowe et al. [34], in modification of Sutton and Simmonds [35]. The reaction mixture contained $0.05 \mathrm{M}$ glutamic acid dissolved in $0.2 \mathrm{M}$ sodium phosphate buffer at $\mathrm{pH} 6.4,14 \mathrm{mM}$ ninhydrin in $0.5 \mathrm{mM}$ carbonate buffer at $\mathrm{pH} 9.9$ and copper tartare reagent made from $1.6 \mathrm{~g} \mathrm{Na}_{2} \mathrm{CO}_{3}, 329 \mathrm{mg}$ tartaric acid and $300 \mathrm{mg}$ of $\mathrm{CuSO}_{4} \cdot 5 \mathrm{H}_{2} \mathrm{O}$ dissolved in $1 \mathrm{~L}$ of water. The tested groups consisted of mice receiving VGB ip in different doses for 3 days or 7 days. The mice in the control group received an adequate amount of vehicle. After decapitation, the mice's brains were removed immediately from their skulls and frozen, then weighed and homogenized in $4 \mathrm{ml}$ of ice-cold $0.01 \mathrm{M} \mathrm{HCl}$. To the samples containing $0.25 \mathrm{ml}$ of the prepared homogenate, $0.25 \mathrm{ml}$ of $0.01 \mathrm{M} \mathrm{HCl}$ and $0.5 \mathrm{ml}$ of $10 \%$ trichloroacetic acid (TCA) were added to denature the proteins. After the samples were centrifuged at $3000 \mathrm{rpm}$ for $20 \mathrm{~min}, 15 \mu \mathrm{l}$ of glutamate solution and $200 \mu \mathrm{l}$ of ninhydrin solution were added to $100 \mu \mathrm{l}$ of the collected supernatants. Later, the samples were incubated for $30 \mathrm{~min}$ at $60{ }^{\circ} \mathrm{C}$. After cooling the samples, $5 \mathrm{ml}$ of copper reagent was added to every test tube. $15 \mathrm{~min}$ later, the fluorescence of the samples was analyzed at $450 \mathrm{~nm}$ with an activating wavelength of $380 \mathrm{~nm}$. Standards were made by adding to homogenate GABA an amount of 12.5-100 $\mu \mathrm{g}$ with $0.2 \mu \mathrm{l}$ of $10 \%$ TCA. By replacing glutamate solution with $15 \mu \mathrm{l}$ of $0.2 \mathrm{M}$ phosphate buffer, the tissue blank was made. GABA levels were calculated as $\mu \mathrm{g} / \mathrm{g}$ of wet brain tissue. 


\section{The analysis of GAD activity in the mouse brain after 7 days of VGB administration}

Total GAD activity was analyzed in the mouse brain homogenates according to the method shown by Lowe et al. [34] and modified by Uchida and O'Brien [36]. In experimental groups mice received VGB in different doses. Mice in the control group received an adequate amount of vehicle. After decapitation the mouse brains were immediately frozen, weighed and homogenized in $4 \mathrm{ml}$ of ice-cold substrate buffer made from $10 \mathrm{ml}$ of $0.2 \mathrm{M}$ phosphate buffer at $\mathrm{pH}$ $6.4,10 \mathrm{ml}$ of $0.1 \mathrm{M}$ glutamic acid in $0.2 \mathrm{M}$ phosphate buffer and $0.4 \mathrm{ml}$ of $150 \mathrm{mM}$ pyridoxal phosphate. Next, $0.2 \mathrm{ml}$ of brain homogenate was stored at $38^{\circ} \mathrm{C}$ for $60 \mathrm{~min}$ and then an equal volume of $10 \%$ TCA was added. The prepared mixture was centrifuged for $20 \mathrm{~min}$ at $3000 \mathrm{rpm}$. From the obtained supernatant, $0.1 \mathrm{ml}$ was transferred to test tubes and then $0.2 \mathrm{ml}$ of $14 \mathrm{mM}$ ninhydrin solution in the carbonate buffer at $\mathrm{pH} 9.9$ was added. Test tubes were stored at $60{ }^{\circ} \mathrm{C}$ for $30 \mathrm{~min}$ and then cooled, and $5.0 \mathrm{ml}$ of copper tartrate was administered to the tubes. After $15 \mathrm{~min}$, the fluorescence was examined at $450 \mathrm{~nm}$ with activating wavelength of $380 \mathrm{~nm}$. GAD activity was expressed in micrograms of GABA per gram of wet brain tissue.

\section{Statistical analysis}

$\mathrm{CD}_{50}, \mathrm{ED}_{50}$ and $\mathrm{TD}_{50}(95 \%$ confidence limits) were calculated and statistically analyzed by computer probit analysis, according to Litchfield Jr. and Wilcoxon [37]. Results obtained from the passive avoidance test were analyzed by Kruskal-Wallis test followed by Dunn's test. AED plasma levels were calculated with the use of unpaired Student's $t$ test. GABA brain concentration and GAD activity analysis was performed using nonparametric ANOVA Kruskal-Wallis test followed by post hoc Dunn's test. Results are shown as mean \pm standard deviation (SD). The $p<0.05$ was set as statistically significant. ANOVA calculations were carried out with GraphPad Prism 6 software.

\section{Results}

\section{Effect of 3 and 7 days of VGB administration on PTZ-induced seizures in mice}

In the mouse PTZ model, the experimentally derived $\mathrm{CD}_{97}$, necessary to induce the clonic phase in mice was $99 \mathrm{mg} / \mathrm{kg}$. 3 days of VGB administration at the dose of
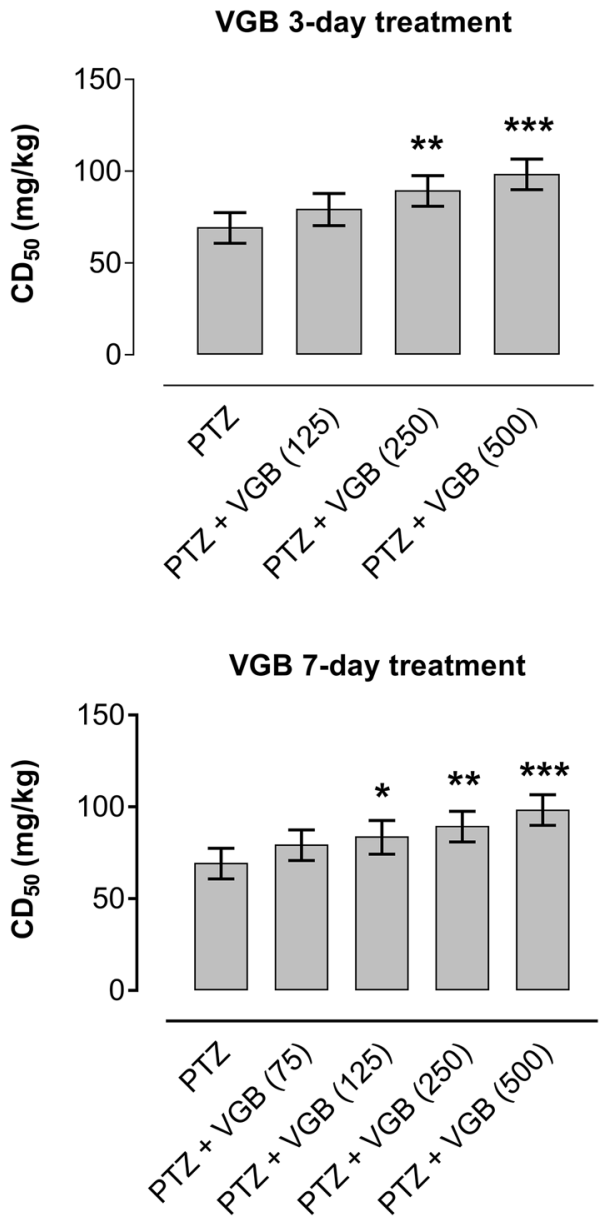

Fig. 1 Influence of 3 and 7 days vigabatrin (VGB) administration on PTZ-induced seizure threshold in mice. VGB was injected intraperitoneally $60 \mathrm{~min}$ before the test. The animals from the control group received $1 \%$ solution of Tween 80 . Each examined group consisted of a minimum of ten animals. Presented data are $\mathrm{CD}_{50}$ values $(95 \%$ confidence limits), calculated as presented by Litchfield Jr. and Wilcoxon [37]. $* p<0.05, * * p<0.01, * * * p<0.001$

$250 \mathrm{mg} / \mathrm{kg}(p<0.01)$ and $500 \mathrm{mg} / \mathrm{kg}(p<0.001)$ significantly increased the seizure threshold in mice (Fig. 1). Moreover, 7 days treatment with VGB at the dose of $125 \mathrm{mg} / \mathrm{kg}(p<0.05), 250 \mathrm{mg} / \mathrm{kg}(p<0.01)$ and $500 \mathrm{mg} /$ $\mathrm{kg}(p<0.001)$ considerably reduced PTZ-induced seizures in mice (Fig. 1).

\section{Effect of 7 days of VGB administration on antiepileptic drugs activity against PTZ-induced seizures in mice}

VGB administration in doses of $75 \mathrm{mg} / \mathrm{kg}$ and $125 \mathrm{mg} /$ $\mathrm{kg}$ for 7 days did not change the anticonvulsive activity of clonazepam, ethosuximide and valproate against PTZinduced seizures in mice (Fig. 2). 

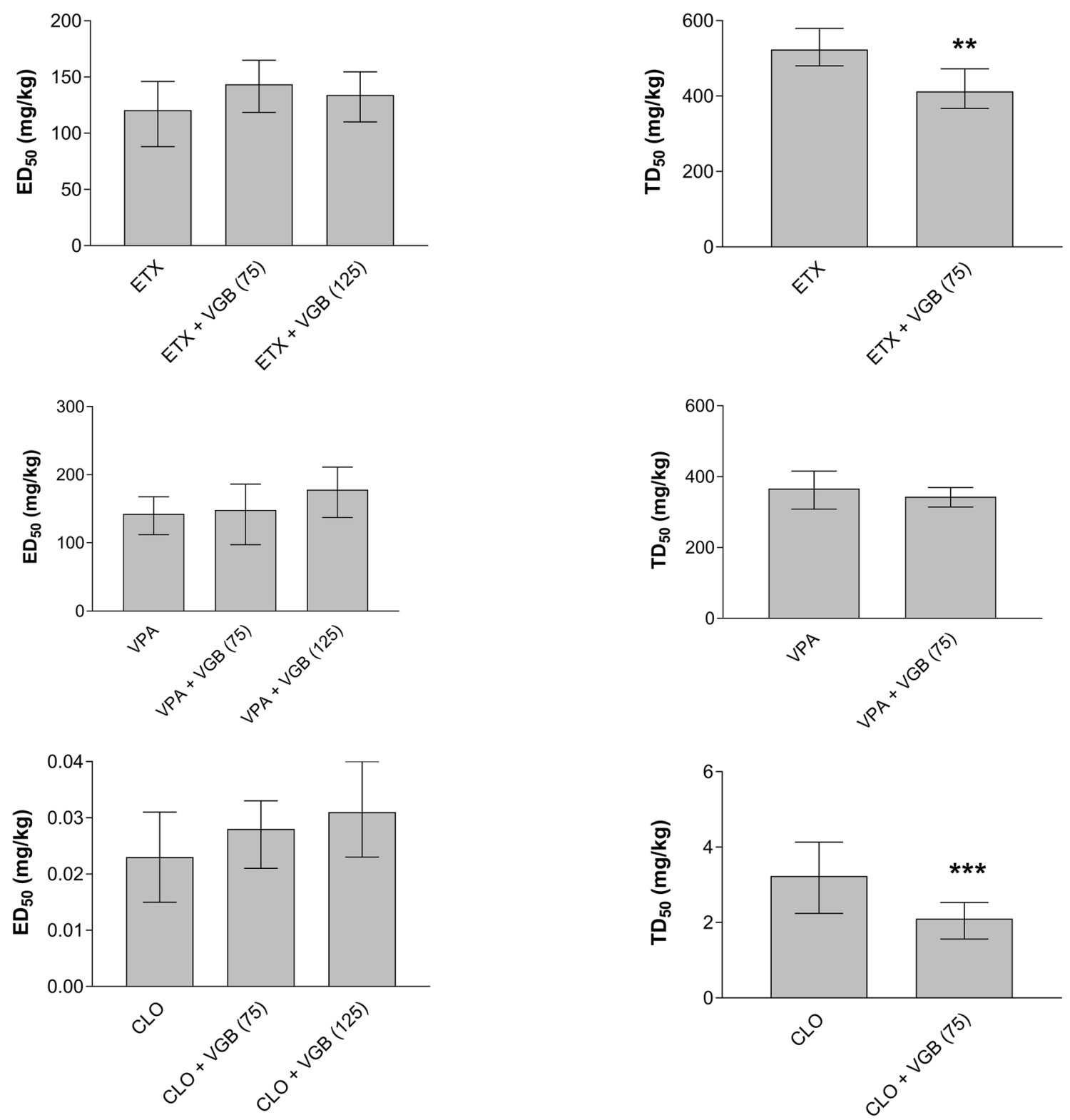

Fig. 2 Influence of 7 days vigabatrin (VGB) administration on antiepileptic drug activity against PTZ-induced seizures in mice. Clonazepam (CLO) and valproate (VPA) were injected intraperitoneally $30 \mathrm{~min}$ before the test; however, ethosuximide (ETX) was given $45 \mathrm{~min}$ before the test. Animals from the control group received distilled water. Each analyzed group had a minimum of ten animals. Data shown are $\mathrm{ED}_{50}$ values $(95 \%$ confidence limits), calculated according to Litchfield Jr. and Wilcoxon [37]

\section{Effect of 7 days of VGB administration on motor impairment after antiepileptic drugs in the chimney test in mice}

VGB at $75 \mathrm{mg} / \mathrm{kg}$, given for 7 days, significantly impaired motor performance in mice treated with ethosuximide $(p<0.01)$ and clonazepam $(p<0.001)$ by reducing their $\mathrm{TD}_{50}$ values (Fig. 3). 7 days of VGB administration had no

Fig. 3 Influence of 7 days vigabatrin (VGB) administration on motor impairment in mice. Clonazepam (CLO), ethosuximide (ETX) and valproate (VPA) were injected intraperitoneally $30 \mathrm{~min}, 30 \mathrm{~min}$ and 45 min before the test, respectively. Presented data are $\mathrm{TD}_{50}$ values of antiepileptic drugs (95\% confidence limits), calculated as reported by Litchfield Jr. and Wilcoxon [37]. **p $p<0.01, * * * p<0.001$

effect on motor coordination in mice receiving VPA and did not significantly change $\mathrm{TD}_{50}$ for VPA (Fig. 3).

\section{Effect of 7 days of VGB administration on long-term memory in the passive avoidance test in mice}

7 days of VGB administration at the dose of $75 \mathrm{mg} / \mathrm{kg}$ alone or together with other AED did not affect long-term memory in the passive avoidance test in mice (Table 1). 
Table 1 The influence of 7 days vigabatrin (VGB) and antiepileptic drug administration on passive avoidance retention tests in mice

\begin{tabular}{lll}
\hline Substance $(\mathrm{mg} / \mathrm{kg})$ & Median & $(25,75$ percentile $)$ \\
\hline Vehicle & 180 & 180,180 \\
Vigabatrin (75) & 172 & 145,180 \\
Ethosuximide (121) & 145 & 116,180 \\
Ethosuximide (144) & 126 & 112,180 \\
Ethosuximide (144) + vigabatrin (75) & 106 & 72,180 \\
Valproic acid (142) & 148 & 94,180 \\
Valproic acid (148) & 154 & 138,180 \\
Valproic acid (148) + vigabatrin (75) & 116 & 80,174 \\
Clonazepam (0.023) & 156 & 124,180 \\
Clonazepam (0.028) & 162 & 122,180 \\
Clonazepam (0.028) + vigabatrin (75) & 122 & 106,178 \\
\hline
\end{tabular}

The presented data are medians with 25 and 75 percentiles of 12 determinations. The retention was analyzed as a time period expressed in seconds during which the animals avoided the dark compartment. Results were analyzed with the use of Kruskal-Wallis test followed by Dunn's post hoc test

\section{Effect of sub-chronic 3 and 7 days of VGB administration on GABA brain level in mice}

Mean GABA concentration in brain homogenates in mice after 3 days of experiment in control animals was $171.94 \pm 15.40 \mu \mathrm{g} / \mathrm{g}$ of wet brain tissue. 3 days of VGB administration at the doses of $250 \mathrm{mg} / \mathrm{kg}, 500 \mathrm{mg} /$ $\mathrm{kg}$ and $750 \mathrm{mg} / \mathrm{kg}$ produced a significant elevation of GABA brain level in mice to $276.39 \pm 20.13 \mu \mathrm{g} / \mathrm{g}$ tissue $(p<0.01), 297.04 \pm 68.68 \mu \mathrm{g} / \mathrm{g}$ tissue $(p<0.01)$ and $404.07 \pm 91.55 \mu \mathrm{g} / \mathrm{g}$ tissue $(p<0.01)$, respectively (Fig. 4$)$.

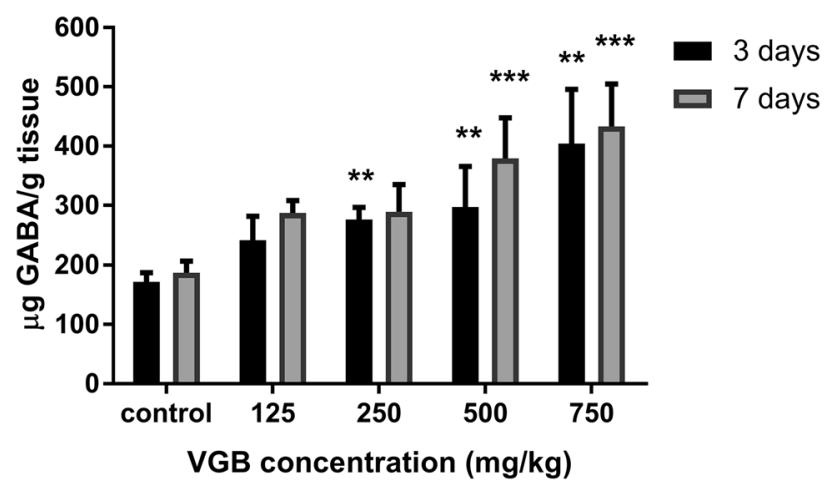

Fig. 4 Influence of 3 and 7 days vigabatrin (VGB) administration on $\gamma$-aminobutyric acid (GABA) brain concentration in mice. The concentration of GABA is expressed in micrograms per gram of wet brain tissue. Data are shown as a mean percentage of control GABA production \pm SD. Results were analyzed with the nonparametric ANOVA Kruskal-Wallis test followed by post hoc Dunn's test. $* * p<0.01$ versus control, $* * * p<0.001$ versus control
After 7 days of experiment, the mean GABA concentration in brain homogenates in mice was $187.14 \pm 19.39 \mu \mathrm{g} / \mathrm{g}$ of wet brain tissue. Mice after 7 days of VGB treatment at the doses of $500 \mathrm{mg} / \mathrm{kg}$ and $750 \mathrm{mg} / \mathrm{kg}$ also had higher GABA brain levels, calculated as $379.29 \pm 68.53 \mu \mathrm{g} / \mathrm{g}$ tissue $(p<0.001)$ and $433.39 \pm 71.14 \mu \mathrm{g} / \mathrm{g}$ tissue $(p<0.001)$, respectively (Fig. 4).

\section{Effect of 3 and 7 days of VGB administration on GAD activity in mice brains}

The mean GAD activity in brain homogenates in mice after 3 days of the study in the control group was $1882 \pm 200 \mu \mathrm{g}$ $\mathrm{GABA} / \mathrm{g}$ tissue. 3 days of VGB administration at the doses of $125 \mathrm{mg} / \mathrm{kg}$ and $250 \mathrm{mg} / \mathrm{kg}$ decreased GAD activity in the brain homogenates in mice to $1222 \pm 367 \mu \mathrm{g} \mathrm{GABA} / \mathrm{g}$ tissue $(p<0.01)$ and $1418 \pm 304 \mu \mathrm{g} \mathrm{GABA} / \mathrm{g}$ tissue $(p<0.01)$, respectively (Fig. 5).

Additionally, after 7 days of the study the mean GAD activity in the brain homogenates in the control mice was $10,248 \pm 490 \mu \mathrm{g} \mathrm{GABA} / \mathrm{g}$ tissue. 7 days of VGB administration at the doses of $125 \mathrm{mg} / \mathrm{kg}, 250 \mathrm{mg} / \mathrm{kg}, 500 \mathrm{mg} /$ $\mathrm{kg}$ and $750 \mathrm{mg} / \mathrm{kg}$ significantly decreased GAD activity to $6643 \pm 1324 \mu \mathrm{g} \mathrm{GABA} / \mathrm{g}$ tissue $(p<0.001), 6414 \pm 1211 \mu \mathrm{g}$ GABA/g tissue $(p<0.001), 6704 \pm 594 \mu \mathrm{g}$ GABA/g tissue $(p<0.001)$ and $6619 \pm 975 \mu \mathrm{g} \mathrm{GABA} / \mathrm{g}$ tissue $(p<0.001)$, respectively (Fig. 5).

\section{Effect of 7 days of VGB administration on plasma and brain antiepileptic drug levels in mice}

VGB given for 7 days at the dose of $75 \mathrm{mg} / \mathrm{kg}$ slightly elevated total plasma ethosuximide concentration from $102.1 \pm 9.8$ to $117.1 \pm 16.7 \mu \mathrm{g} / \mathrm{ml}$ (data not shown), although

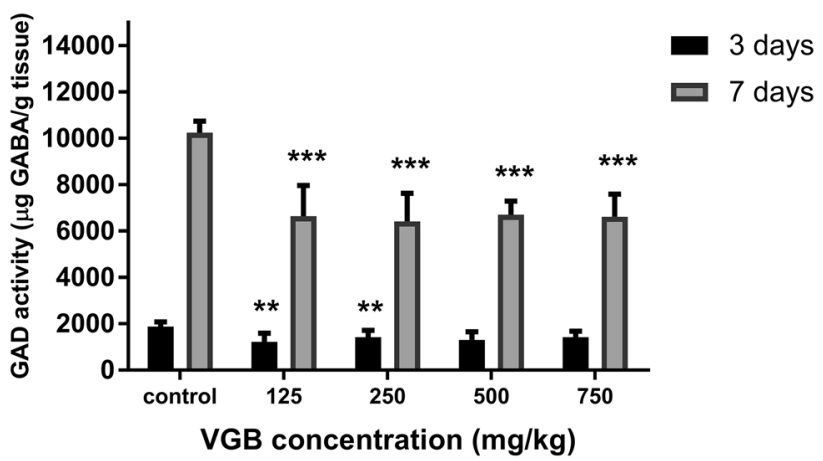

Fig. 5 Influence of 3 and 7 days vigabatrin (VGB) administration on glutamate dehydrogenase (GAD) activity in mice brains. The activity of GAD is expressed in micrograms of GABA per gram of wet tissue. Data are shown as a mean percentage of control GABA production \pm SD. Results were analyzed with the nonparametric ANOVA Kruskal-Wallis test followed by post hoc Dunn's test. ${ }^{* *} p<0.01$ versus control, $* * * p<0.001$ versus control 
VGB did not affect brain concentrations of ethosuximide. On the contrary, VGB did not change the plasma and brain level of clonazepam and valproate in the examined mice (data not shown).

\section{Discussion}

In the present study, it was shown that 3 days and chronic 7 days of VGB administration suppressed PTZ-induced clonic seizures in mice. However, VGB given for 7 days in combination with ethosuximide, clonazepam or valproate did not substantially change their anticonvulsive activity. When compared to single AED injections, VGB in combination with ethosuximide or clonazepam worsened motor coordination in mice. However, after VGB administration with valproate, motor disfunction in mice was not observed. Additionally, 7 days of VGB administration alone or together with ethosuximide, clonazepam or valproate did not significantly disturb long-term memory in the passive avoidance task in mice. After 7 days of VGB administration, a slight increase in ethosuximide plasma concentrations in mice was observed, whereas clonazepam and valproate plasma levels did not change. Additionally, VGB treatment did not affect the brain level of the analyzed AEDs. 3 days and 7 days of VGB administration led to a significant elevation of GABA concentration in the mouse brains. Moreover, VGB given for 3-7 days lowered GAD activity in the mouse's brain.

It is well documented that the anticonvulsive activity of VGB is related to an increase in the central nervous system GABA level [38, 39]. Except for GABA-AT inhibition, stimulation of GABA release from synaptosomes is also considered as VGB's mechanism of action [40]. Other AEDs, like valproate or clonazepam have also been shown to possess GABA enhancing property. A combination of GABA-related drugs, especially VGB and gabapentin [41] or tiagabine [42], produced favorable additive or synergistic interactions depending on drugs fixed ratio in the mouse model of PTZ-induced clonic seizures. Unfortunately, the anticonvulsive activity of valproate, clonazepam and ethosuximide was not changed after 7 days of VGB administration in PTZ-induced seizures in mice. Also, a slight elevation in plasma concentration of ethosuximide was observed, whereas plasma levels of other AEDs were unaffected. Contrary to that, Łuszczki et al. [43] have reported that VGB given in combination with ethosuximide exerts synergistic interaction against PTZ-induced seizures in mice. Additionally, an elevation in ethosuximide brain level was presented, although valproate and phenobarbital concentrations did not change in the experimental animals. The differences between our results and those previously published might be due to a longer time of observation in the presented paper. Despite the fact that VGB presents great pharmacokinetic profile
[44], about $17.1 \%$ of total plasma of VGB is bound to protein and may be responsible for drug interactions. Pharmacokinetic interactions on cytochrome P-450 level should be excluded, since VGB is mainly secreted in the urine and not metabolized through liver enzymes [45]. However, 7 days of VGB administration seems to be safe and did not significantly change the anticonvulsive properties of the examined AEDs and their plasma levels.

There has been evidence reporting that besides the antiseizure activity, AEDs possess neuroprotective properties. In the pilocarpine model of temporal lobe epilepsy, VGB was reported to prevent hippocampal damage in rats [46]. Cuadrado et al. [47] showed that VGB can slightly decrease valproate's neurotoxicity, with significant increase in brain GABA content in the mouse model of PTZ-induced clonic seizures. What is more, Gey et al. [48] reported that VGB infusion into the subthalamic nucleus in rats lasting 3 weeks effectively increases local GABA concentration. Similar to that, in our study during 3 or 7 days of VGB administration, a significant elevation in brain GABA concentration was observed in mice, with concomitant reduction in GAD activity. This result seems to be expected, since lower GAD activity was previously linked with VGB activity, especially after its prolonged administration [49]. In fact, there is a growing body of evidence suggesting that GABA analogs decrease GAD and GABA-AT brain activity in a similar manner [50]. Comparable results were demonstrated by Rimvall et al. after incubating cerebral cortical neurons cultures with VGB [51].

In conclusion, the presented results indicate that 3 days or 7 days of VGB treatment provides an effective anticonvulsive effect in PTZ-induced seizures. Lack of significant pharmacokinetic interactions with AED confirms the safety of long-term VGB administration.

Acknowledgements Open access publishing of this article was funded by the Ministry of Science and Higher Education under the agreement No. 879/P-DUN/2019. This study was supported by the State Committee for Scientific Research (KBN) Grant No. 3PO5F03523.

\section{Compliance with ethical standard}

Conflict of interest On behalf all co-authors I would like to confirm that there are no known conflicts of interestassociated with this publication and there has been no significant financial support for this work that could have influenced its outcome.

Open Access This article is licensed under a Creative Commons Attribution 4.0 International License, which permits use, sharing, adaptation, distribution and reproduction in any medium or format, as long as you give appropriate credit to the original author(s) and the source, provide a link to theCreative Commons licence, and indicate if changes were made. The images or other third party material in this article are included in the article's Creative Commons licence, unless indicated otherwise in a credit line to the material. If material is not included in the article's Creative Commons licence and your intended use is not 
permitted by statutory regulation or exceeds the permitted use, you will need to obtain permission directly from the copyright holder. To view a copy of this licence, visit http://creativecommons.org/licenses/by/4.0/.

\section{References}

1. Tang F, Hartz AMS, Bauer B. Drug-resistant epilepsy: multiple hypotheses few answers. Front Neurol. 2017;8:301.

2. Duble SN, Thomas SV. Sudden unexpected death in epilepsy. Indian J Med Res. 2017;145(6):738-45.

3. Nakken KO, Taubøll E. Drug-resistant epilepsy. Tidsskr Nor Laegeforen. 2009;129(19):1986-9.

4. Mäkinen J, Rainesalo S, Raitanen J, Peltola J. The effect of newer antiepileptic drugs in combination therapy. Epilepsy Res. 2017;132:15-20.

5. Joshi R, Tripathi M, Gupta P, Gulati S, Gupta YK. Adverse effects \& drug load of antiepileptic drugs in patients with epilepsy: monotherapy versus polytherapy. Indian J Med Res. 2017;145(3):317-26.

6. Hu Q, Zhang F, Teng W, Hao F, Zhang J, Yin M, Wang N. Efficacy and safety of antiepileptic drugs for refractory partial-onset epilepsy: a network meta-analysis. J Neurol. 2017. https://doi. org/10.1007/s00415-017-8621-x.

7. Gale K, Iadarola MJ. Seizure protection and increased nerve-terminal GABA: delayed effects of GABA transaminase inhibition. Science. 1980;208(4441):288-91.

8. Ben-Menachem E, Persson LI, Mumford J, Haegele KD, Huebert $\mathrm{N}$. Effect of long-term vigabatrin therapy on selected neurotransmitter concentrations in cerebrospinal fluid. J Child Neurol. 1991;Suppl 2:S11-6.

9. Liu Z, Seiler N, Marescaux C, Depaulis A, Vergnes M. Potentiation of gamma-vinyl GABA (vigabatrin) effects by glycine. Eur J Pharmacol. 1990;182(1):109-15.

10. Halonen T, Pitkänen A, Saano V, Riekkinen PJ. Effects of vigabatrin (gamma-vinyl GABA) on neurotransmission-related amino acids and on GABA and benzodiazepine receptor binding in rats. Epilepsia. 1991;32(2):242-9.

11. Engelborghs S, Pickut BA, D'Hooge R, Wiechert P, Haegele K, De Deyn PP. Behavioral effects of vigabatrin correlated with whole brain gamma-aminobutyric acid metabolism in audiogenic sensitive rats. Arzneimittelforschung. 1998;48(7):713-6.

12. Turski L, Cavalheiro EA, Schwarz M, Turski WA, De Moraes Mello LE, Bortolotto ZA, Klockgether T, Sontag KH. Susceptibility to seizures produced by pilocarpine in rats after microinjection of isoniazid or gamma-vinyl-GABA into the substantia nigra. Brain Res. 1986;370(2):294-309.

13. Löscher W, Czuczwar SJ, Jäckel R, Schwarz M. Effect of microinjections of gamma-vinyl GABA or isoniazid into substantia nigra on the development of amygdala kindling in rats. Exp Neurol. 1987;95(3):622-38.

14. Liu Z, Vergnes M, Depaulis A, Marescaux C. Evidence for a critical role of GABAergic transmission within the thalamus in the genesis and control of absence seizures in the rat. Brain Res. 1991;545(1-2):1-7.

15. Sayin U, Cengiz S, Altug T. Vigabatrin as an anticonvulsant against pentylenetetrazol seizures. Pharmacol Res. 1993;28(4):325-31.

16. Halonen T, Miettinen R, Toppinen A, Tuunanen J, Kotti T, Riekkinen PJ Sr. Vigabatrin protects against kainic acid-induced neuronal damage in the rat hippocampus. Neurosci Lett. 1995;195(1):13-6.

17. Kubová H, Mares P. Hypoxia-induced changes of seizure susceptibility in immature rats are modified by vigabatrin. Epileptic Disord. 2007;9(Suppl 1):S36-43.
18. Zhang B, McDaniel SS, Rensing NR, Wong M. Vigabatrin inhibits seizures and mTOR pathway activation in a mouse model of tuberous sclerosis complex. PLoS ONE. 2013;8(2):e57445.

19. Hemming K, Maguire MJ, Hutton JL, Marson AG (2008) Vigabatrin for refractory partial epilepsy. Cochrane Database Syst Rev (3):CD007302.

20. Jambaqué I, Chiron C, Dumas C, Mumford J, Dulac O. Mental and behavioural outcome of infantile epilepsy treated by vigabatrin in tuberous sclerosis patients. Epilepsy Res. 2000;38(2-3):151-60.

21. Marciani MG, Maschio M, Spanedda F, Iani C, Gigli GL, Bernardi G. Development of myoclonus in patients with partial epilepsy during treatment with vigabatrin: an electroencephalographic study. Acta Neurol Scand. 1995;91(1):1-5.

22. Grant SM, Heel RC. Vigabatrin. A review of its pharmacodynamic and pharmacokinetic properties, and therapeutic potential in epilepsy and disorders of motor control. Drugs. 1991;41(6):889-926.

23. Turjanski N, Lees AJ. Gamma vinyl GABA in the treatment of levodopa-induced dyskinesias in Parkinson's disease. J Neurol Neurosurg Psychiatry. 1992;55(5):413.

24. Sander JW, Hart YM, Trimble MR, Shorvon SD. Vigabatrin and psychosis. J Neurol Neurosurg Psychiatry. 1991;54(5):435-9.

25. Pellock JM. Balancing clinical benefits of vigabatrin with its associated risk of vision loss. Acta Neurol Scand. 2011;Suppl 192:83-91.

26. Swiader M, Łuszczki J, Wielosz M, Czuczwar SJ. Influence of vigabatrin, a novel antiepileptic drug, on the anticonvulsant activity of conventional antiepileptics in pentetrazole-induced seizures in mice. Pol J Pharmacol. 2003;55(3):363-70.

27. Czuczwar SJ, Małek U, Kleinrok Z. Influence of calcium channel inhibitors upon the anticonvulsant efficacy of common antiepileptics against pentylenetetrazol-induced convulsions in mice. Neuropharmacology. 1990;29(10):943-8.

28. Gasior M, Kamiński R, Brudniak T, Kleinrok Z, Czuczwar SJ. Influence of nicardipine, nimodipine and flunarizine on the anticonvulsant efficacy of antiepileptics against pentylenetetrazol in mice. J Neural Transm (Vienna). 1996;103(7):819-31.

29. Bernasconi R, Klein M, Martin P, Christen P, Hafner T, Portet C, Schmutz M. Gamma-vinyl GABA: comparison of neurochemical and anticonvulsant effects in mice. J Neural Transm. 1988;72(3):213-33.

30. Boissier JR, Tardy J, Diverres JC. Une nouvelle méthode simple pour explorer l'action 'tranquillisante': le test de la cheminée. Med. Exp. 1960;3:81-4.

31. Venault P, Chapouthier G, de Carvalho LP, Simiand J, Morre M, Dodd RH, Rossier J. Benzodiazepine impairs and beta-carboline enhances performance in learning and memory tasks. Nature. 1986;321(6073):864-6.

32. Czuczwar SJ, Janusz W, Szczepanik B, Wamil A, Kleinrok Z. Effect of aminophylline upon the protective activity of common antiepileptic drugs and their plasma levels in mice. Neurosci Res. 1989;6(5):470-4.

33. Świąder MJ, Barczyński B, Tomaszewski M, Świąder K, Czuczwar SJ. The effects of cimetidine chronic treatment on conventional antiepileptic drugs in mice. Pharmacol Rep. 2016;68(2):283-8.

34. Lowe IP, Robins E, Eyerman GS. The fluorometric measurement of glutamic decarboxylase and its distribution in brain. J Neurochem. 1958;3(1):8-18.

35. Sutton I, Simmonds MA. Effects of acute and chronic pentobarbitone on the gamma-aminobutyric acid system in rat brain. Biochem Pharmacol. 1974;23(13):1801-8.

36. Uchida T, O'Brien RD. The effects of hydrazines on rat brain 5-hydroxytryptamine, norepinephrine, and gamma-aminobutyric acid. Biochem Pharmacol. 1964;13:725-30. 
37. Litchfield JT Jr., Wilcoxon F. A simplified method of evaluating dose-effect experiments. J Pharmacol Exp Ther. 1949;96(2):99-113.

38. Piredda S, Pavlick M, Gale K. Anticonvulsant effects of GABA elevation in the deep prepiriform cortex. Epilepsy Res. 1987;1(2):102-6.

39. Walters DC, Arning E, Bottiglieri T, Jansen EEW, Salomons GS, Brown MN, Schmidt MA, Ainslie GR, Roullet JB, Gibson KM. Metabolomic analyses of vigabatrin (VGB)-treated mice: GABA-transaminase inhibition significantly alters amino acid profiles in murine neural and non-neural tissues. Neurochem Int. 2019;125:151-62.

40. Abdul-Ghani AS, Norris PJ, Smith CC, Bradford HF. Effects of gamma-acetylenic GABA and gamma-vinyl GABA on synaptosomal release and uptake of GABA. Biochem Pharmacol. 1981;30(11):1203-9.

41. Luszczki JJ, Ratnaraj N, Patsalos PN, Czuczwar SJ. Isobolographic and behavioral characterizations of interactions between vigabatrin and gabapentin in two experimental models of epilepsy. Eur J Pharmacol. 2008;595(1-3):13-21.

42. Luszczki JJ, Czuczwar SJ. Isobolographic characterization of interactions between vigabatrin and tiagabine in two experimental models of epilepsy. Prog Neuropsychopharmacol Biol Psychiatry. 2007;31(2):529-38.

43. Luszczki JJ, Wojcik-Cwikla J, Andres MM, Czuczwar SJ. Pharmacological and behavioral characteristics of interactions between vigabatrin and conventional antiepileptic drugs in pentylenetetrazole-induced seizures in mice: an isobolographic analysis. Neuropsychopharmacology. 2005;30(5):958-73.

44. Patsalos PN, Zugman M, Lake C, James A, Ratnaraj N, Sander JW. Serum protein binding of 25 antiepileptic drugs in a routine clinical setting: a comparison of free non-protein-bound concentrations. Epilepsia. 2017;58(7):1234-43.
45. Elwes RD, Binnie CD. Clinical pharmacokinetics of newer antiepileptic drugs. Lamotrigine, vigabatrin, gabapentin and oxcarbazepine. Clin Pharmacokinet. 1996;30(6):403-15.

46. André V, Ferrandon A, Marescaux C, Nehlig A. Vigabatrin protects against hippocampal damage but is not antiepileptogenic in the lithium-pilocarpine model of temporal lobe epilepsy. Epilepsy Res. 2001;47(1-2):99-117.

47. Cuadrado A, Armijo JA. Beneficial interaction between vigabatrin and valproate against seizures induced by pentylenetetrazole in mice. Pharmacol Res. 2005;51(5):489-96.

48. Gey L, Gernert M, Löscher W. Continuous bilateral infusion of vigabatrin into the subthalamic nucleus: effects on seizure threshold and GABA metabolism in two rat models. Neurobiol Dis. 2016;91:194-208.

49. Valdizán EM, Armijo JA. Effects of single and multiple increasing doses of vigabatrin on brain GABA metabolism and correlation with vigabatrin plasma concentration. Biochem Pharmacol. 1992;43(10):2143-50.

50. Cubells JF, Blanchard JS, Smith DM, Makman MH. In vivo action of enzyme-activated irreversible inhibitors of glutamic acid decarboxylase and gamma-aminobutyric acid transaminase in retina vs. brain. J Pharmacol Exp Ther. 1986;238(2):508-14.

51. Rimvall K, Martin DL. Increased intracellular gamma-aminobutyric acid selectively lowers the level of the larger of two glutamate decarboxylase proteins in cultured GABAergic neurons from rat cerebral cortex. J Neurochem. 1992;58(1):158-66.

Publisher's Note Springer Nature remains neutral with regard to jurisdictional claims in published maps and institutional affiliations. 